\title{
TERPAAN IKLAN TELEVISI DAN SIKAP IBU RUMAH TANGGA DI PEDESAAN TERHADAP MAKANAN OLAHAN PABRIK
}

\author{
Amalia Dianah $^{1}$, Nurmala Katrina Panjaitan², Eko Sri Mulyani ${ }^{3}$ \\ ${ }^{1}$ Staf Pengajar SMP Al Umanaa Boarding School \\ ${ }^{2}$ Staf Pengajar Fakultas Ekologi Manusia, Institut Pertanian Bogor \\ ${ }^{3}$ Kepala Bidang KSPHP Puslitbang Tanaman Pangan, Kementan RI \\ email: amalia_dianah@yahoo.com
}

Naskah diterima: 26 Januari 2016; Direvisi: 22 April 2016; Disetujui: 30 Mei 2016

\begin{abstract}
$T V$ food advertisements are designed to cultivate positive portrait of the food advertised. Married rural women have dominant role in providing food for family and more possibility to make TV as the main source of information about food. The study aimed to examine the exposure of TV advertisements about industrial processed food on married rural women, the attitude of married rural women towards industrial processed food, and to analyse relationship between the exposure of TV advertisements and the attitude towards industrial processed food. Based on a survey conducted on 104 married rural women with children, who were TV audience and aged 20-60 in Curugbitung Village, Nanggung District, Bogor Regency, it was known that TV food advertisements exposure of respondents were moderate (56\%) and high (44\%), while their attitude towards industrial processed food were positive (27\%) and neutral (73\%). A highly significant positive correlation $(r=0.254, p<0.01)$ between TV food advertisements and attitude towards industrial processed food on respondents was revealed by Spearman's rank test. The results implicated that food TV advertisements were not respondents' main source of information about food. Analysis of total food TV content and interpersonal information channel of married rural women would be necessary.
\end{abstract}

Keywords : attitude, exposure, processed food, rural women, TV advertisement

\section{PENDAHULUAN}

Perkembangan teknologi pengolahan pangan telah menghasilkan berbagai produk makanan dengan berbagai kemudahan konsumsi. Fenomena ini berhasil menggeser pola makan masyarakat Indonesia, dari menyantap makanan yang dimasak di rumah ke arah makanan olahan jadi (Setyawati 2013). Data Survei Sosial Ekonomi Nasional (Susenas) selama tahun 2008-2011 mengindikasikan bahwa masyarakat mulai meninggalkan pangan segar dan beralih ke pangan olahan. Mustamar et al. (2015) mengidentifikasi pergeseran pilihan makanan jajanan masyarakat desa dari makanan ringan tradisional ke makanan ringan kemasan produksi pabrik. Produk-produk makanan olahan juga diidentifikasi telah merambah ke daerah pedesaan (Darojah 2012). Tren konsumsi di atas turut dipicu oleh maraknya iklan makanan olahan di berbagai media massa, khususnya televisi.

Warren et al. (2008) mengidentifikasi lima daya tarik yang paling sering ditampilkan oleh iklan makanan di TV, antara lain: rasa atau aroma, perubahan suasana hati (mood), kandungan gizi, kebaruan, dan harga terjangkau. Sebagaimana analisis konten yang dilakukan Kean dan Prividera (2007), iklan makanan dirancang dengan menampilkan kesan kelezatan dan kenikmatan mengonsumsi produk serta klaim nutrisi atau manfaat kesehatan bagi 
konsumen. Peringatan terhadap dampak negatif dari mengonsumsi makanan olahan tidak dikemukakan dalam iklan makanan komersial di TV. Padahal makanan-makanan yang diiklankan di TV adalah makanan olahan yang diproses dengan teknologi tinggi (pabrikasi). Kandungan bahan pangan buatan dalam produk-produk makanan olahan pabrik tersebut dapat berdampak buruk bagi kesehatan jika dikonsumsi terus menerus.

Analisis kultivasi digunakan untuk menggambarkan kontribusi independen dari menonton TV pada konsepsi penonton terhadap realitas sosial (Bryant dan Zillmann 2002). Peneliti kultivasi percaya bahwa semakin sering khalayak menonton $\mathrm{TV}$, persepsi dan sikap yang dimiliki terhadap objek yang dipotret media akan semakin serupa dengan citra/gambaran yang ditampilkan di TV (Kean et al. 2012). Hal ini dibuktikan diantaranya oleh Russel dan Buhrau (2015) yang menemukan bahwa remaja pemirsa TV kelas berat (heavy viewers) memiliki lebih banyak kepercayaan positif dan lebih sedikit kepercayaan negatif tentang konsekuensi mengonsumsi makanan cepat saji dibandingkan dengan pemirsa TV kelas ringan (light viewers).

Iklan makanan di TV juga ditemukan mempengaruhi perilaku konsumsi. Sumarwan et al. (2012) menemukan peningkatan konsumsi makanan ringan pada anak-anak sejalan dengan peningkatan frekuensi tayang iklan makanan ringan di TV. Terpaan konten media berupa program-program TV yang berhubungan dengan makanan juga ditemukan berdampak pada meningkatnya konsumsi makananmakanan manis pada khalayak
(Bodenlos dan Wormuth 2013). Harris et al. (2009) mendapatkan bahwa anak-anak dan orang dewasa yang terpapar oleh iklan-iklan makanan mengonsumsi lebih banyak makanan dibandingkan dengan yang tidak terpapar.

$$
\text { San Joaquin }
$$

menemukan bahwa anak-anak yang termasuk pemirsa kelas berat (heavy viewers) memperoleh lebih banyak informasi tentang nilai gizi makanan dari sumber interpersonal, yaitu orang tua. Peran orang tua sebagai penentu asupan anak-anak juga diidentifikan oleh Valkenburg (2004). (Arsil, Li, dan Buwer 2014) mengidentifikasi bahwa kebiasaan makan anak-anak dibentuk di dalam keluarga, dimana ibu rumah tangga di Indonesia umumnya memiliki peran dominan dalam menyediakan makanan untuk keluarga. Dengan demikian, persepsi dan sikap ibu rumah tangga tentang makanan yang diiklankan akan mempengaruhi pilihan makanan keluarga.

Persepsi merupakan komponen kognitif dari sikap. Adapun sikap adalah evaluasi terhadap berbagai aspek dalam dunia sosial, yang dapat memunculkan rasa suka atau tidak suka terhadap suatu isu, ide, orang, kelompok sosial, dan objek, termasuk pada makanan (Baron dan Byrne 2004). Tuu et al. (2008) mengidentifikasi adanya pengaruh positif sikap terhadap keinginan mengonsumsi ikan di Vietnam. Sikap terhadap produk daging olahan beku dalam penelitian Ahmadi et al. (2010) juga ditemukan mempengaruhi niat pembelian ulang produk.

Mengingat televisi kini telah dimiliki oleh hampir setiap rumah dan menjangkau daerah pedesaan, keberadaan produk-produk makanan 
olahan di pedesaan berpeluang memperkuat efek persuasif dari iklan makanan di TV. Selain berdampak menghambat program diversifikasi pangan dan menurunkan kualitas kesehatan, kebiasaan mengonsumsi makanan olahan pabrik akan mengancam pelestarian makanan tradisional dan mengakibatkan pengeluaran yang tidak efektif dan efisien, khususnya pada rumah tangga di pedesaan. Karakter masyarakat pedesaan yang umumnya memiliki tingkat pendidikan dan kosmopolitan rendah, menyebabkan televisi memiliki peran penting dalam sosialisasi informasi, termasuk tentang makanan.

Berdasarkan permasalahan yang telah diuraikan, penelitian ini bertujuan untuk: (1) mengetahui terpaan iklan televisi makanan olahan pabrik pada ibu rumah tangga di pedesaan, (2) mengetahui sikap ibu rumah tangga di pedesaan terhadap makanan olahan pabrik, dan (3) menganalisis hubungan antara terpaan iklan televisi makanan olahan pabrik dan sikap ibu rumah tangga di pedesaan tentang makanan olahan pabrik.

\section{METODE PENELITIAN}

Penelitian ini didesain sebagai penelitian survei, dengan pendekatan kuantitatif, didukung data kualitatif. Penelitian dilaksanakan Desa Curug Bitung, Kecamatan Nanggung, Kabupaten Bogor. Jumlah responden 104 orang, ditentukan secara sengaja (purposive sampling) sesuai dengan karakteristik yang dibutuhkan penelitian, yaitu ibu rumah tangga berusia 20-60 tahun yang merupakan pemirsa TV dan memiliki anak. Analisis data menggunakan analisis statistik deskriptif dan analisis statistik inferensial dengan uji statistik non-parametrik Spearman's Rank Correlation (Korelasi Spearman) menggunakan SPSS versi 22.

\section{HASIL DAN PEMBAHASAN}

Ibu rumah tangga yang menjadi responden penelitian berusia 31-45 tahun (46\%), 20-30 tahun (33\%), dan 46-60 tahun (21\%). Pendidikan tertinggi responden adalah tamat SMP yang ditempuh oleh 5\% responden. Sebanyak 56\% responden tamat SD, sedangkan 39\% lainnya tidak tamat SD atau tidak bersekolah. Dalam hal mata pencaharian, sebagian besar Ibu rumah tidak bekerja. Adapun kepala keluarga umumnya adalah buruh tani, yang beberapa diantaranya juga menjadi buruh bangunan atau buruh pertambangan liar.

\section{Tingkat Kosmopolitan}

Tingkat kosmopolitan hampir seluruh responden (99\%) rendah, dimana sebagian besar responden tidak pernah bepergian ke kota, jarang ke pasar tradisional, tidak pernah ke minimarket, dan hampir seluruh responden hanya memiliki televisi sebagai media informasi. Hanya $1 \%$ responden yang memiliki tingkat kosmopolitan sedang. Indikator tingkat kosmopolitan meliputi keterdedahan responden terhadap kota, tempat perbelanjaan, dan media massa selama satu tahun terakhir.

Dilihat dari keterdedahan terhadap kota, mayoritas responden tidak pernah bepergian ke kota. Responden yang berkunjung ke kota dalam taraf sering hanya $2 \%$, jarang $1 \%$, dan selebihnya sangat jarang (Gambar 1). Kota tujuan yang dikunjungi adalah Bogor, Jakarta, 
ISSN 1693-3699

dan Banten. Tujuan responden ke kota pada umumnya adalah mengunjungi keluarga atau saudara. Adapun responden yang berkunjung ke Jakarta bertujuan mengantar adiknya mencari kerja.

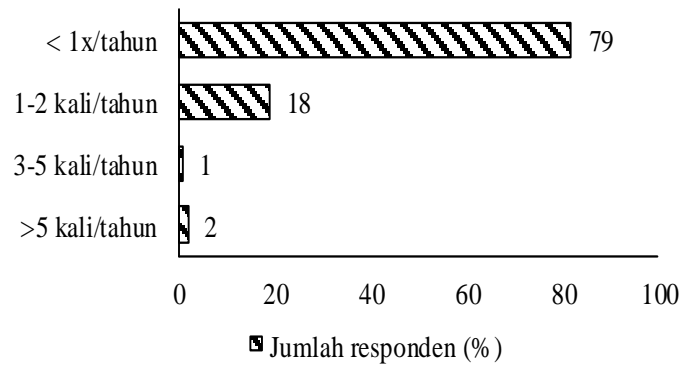

Gambar 1 Frekuensi responden berkunjung ke kota

Tempat perbelanjaan di luar wilayah responden yang paling banyak dikunjungi adalah pasar tradisional (Gambar 2). Sebanyak $53 \%$ hanya pernah berbelanja ke pasar tradisional, $27 \%$ responden berbelanja ke pasar tradisional dan minimarket, $1 \%$ responden berbelanja ke pasar tradisional, minimarket, supermarket, dan mall, sedangkan selebihnya (19\%) tidak pernah berbelanja ke luar wilayahnya, melainkan hanya ke warung sekitar.

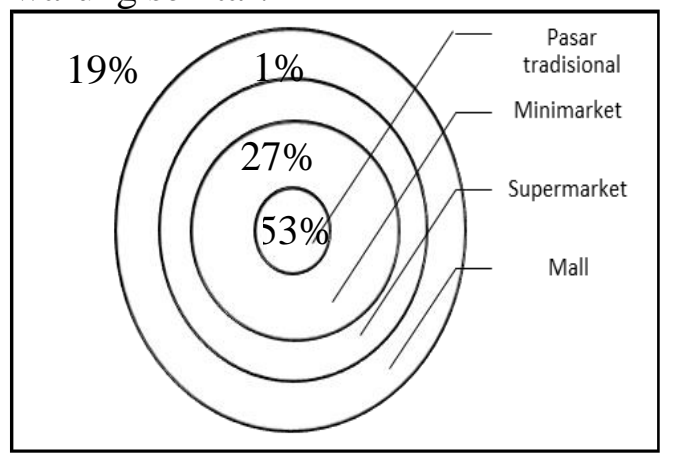

Gambar 2 Tempat perbelanjaan responden

Dalam indikator frekuensi berbelanja, hampir seluruh responden $(99 \%)$ tidak pernah ke
Jurnal Komunikasi Pembangunan Juli 2016 Vol 14, No 2

supermarket ataupun mal dan sebagian besar (72\%) tidak pernah berbelanja ke minimarket (Gambar 3). Meski hampir seluruh responden berbelanja ke pasar tradisional (76\%), hanya responden pemilik warung yang berbelanja ke pasar tradisional dalam kategori sangat sering $(6 \%)$.

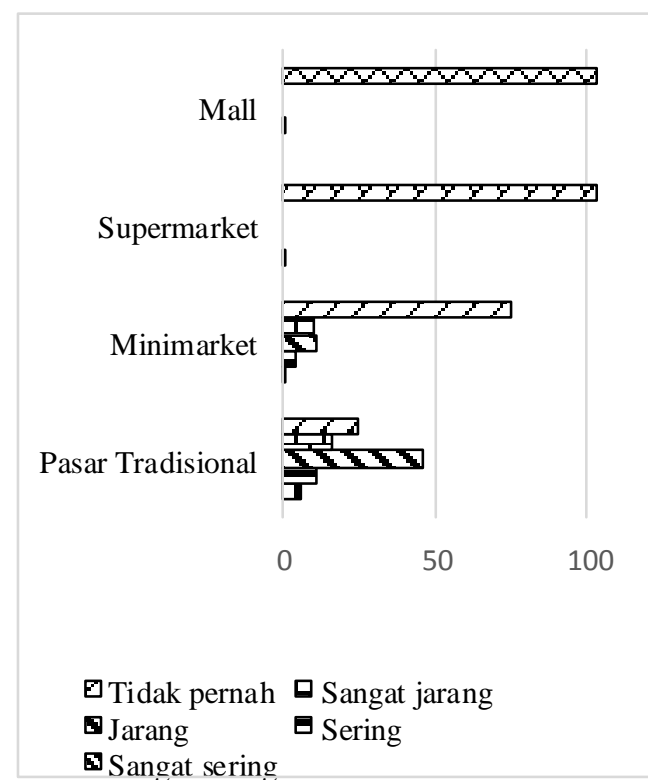
Gambar 3 Frekuensi responden berkunjung ke tempat perbelanjaan

Indikator berikutnya dari tingkat kosmopolitan adalah keterdedahan terhadap media. Hampir seluruh responden (99\%) hanya mengonsumsi media televisi. Radio sudah tidak didengar lagi, sementara media cetak seperti koran dan tabloid belum menjadi konsumsi masyarakat. Hal ini diperkuat dengan tidak adanya penjual media cetak di pasar tradisional terdekat, yang merupakan pasar kecamatan. Sedangkan internet hanya dikonsumsi oleh seorang responden yang merupakan pendatang dari Jawa Timur dan baru tiga tahun tinggal di lokasi penelitian. 
ISSN 1693-3699

\section{Pengalaman Konsumsi Makanan Olahan Pabrik}

Makanan olahan pabrik yang paling banyak dikonsumsi oleh ibu rumah tangga adalah bumbu penyedap masakan (Gambar 4). Kategori makanan olahan pabrik yang paling banyak dikonsumsi berturut-turut selanjutnya adalah mi instan, makanan ringan, es krim, makanan olahan daging, dan bumbu olahan (termasuk tepung bumbu).

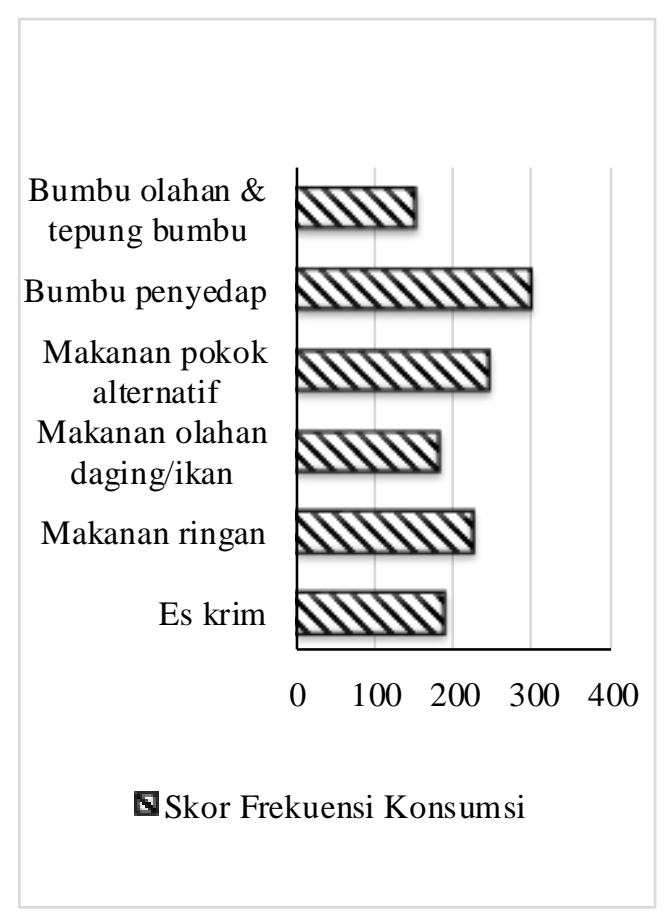
Gambar 4 Konsumsi makanan olahan pabrik rumah tangga responden berdasarkan skor frekuensi konsumsi

Hampir seluruh responden mengonsumsi bumbu penyedap, sebagaimana terlihat pada Gambar 5. Terdapat kemiripan cara menggunakan bumbu penyedap, dimana responden yang memiliki balita dan anak-anak lebih memilih bumbu penyedap non-MSG. Hal ini dilakukan atas informasi yang diperoleh dari posyandu, bidan, atau
Jurnal Komunikasi Pembangunan Juli 2016 Vol 14, No 2

mahasiswa yang pernah kuliah kerja praktek di wilayah mereka. Bumbu penyedap yang mengandung MSG dinyatakan lebih disukai, sehingga responden cenderung menggunakannya dalam hidangan yang diperuntukkan bagi dirinya sendiri atau orang tuanya.

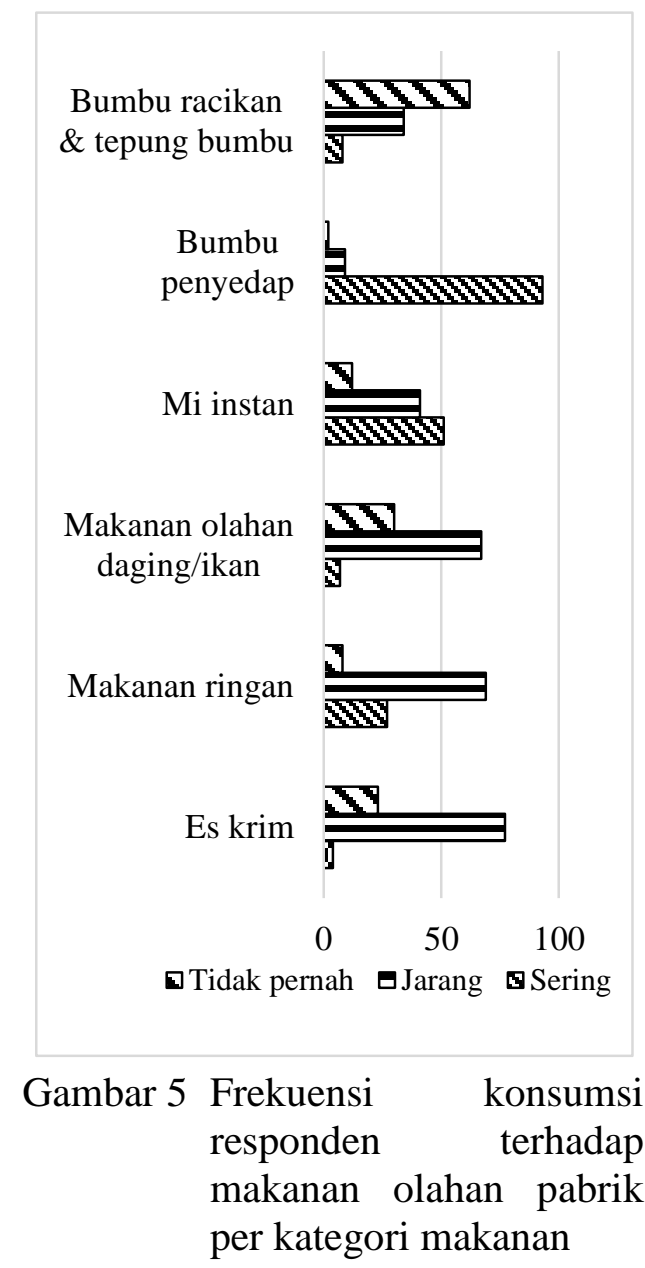

Lain halnya dengan mi instan yang dikonsumsi secara beragam oleh rumah tangga responden. Responden yang sering mengonsumsi mi instan (49\%) menyatakan bahwa alasan utama mengonsumsinya adalah karena enak rasanya, terjangkau harganya, dan dapat diperoleh di warung terdekat. Responden yang jarang mengonsumsinya (39\%) memiliki alasan kesehatan dan ketidaksenangan terhadap rasa mi 
ISSN 1693-3699

instan. Sedangkan responden yang tidak pernah mengonsumsi mi instan menyatakan alasan tidak menyukai rasanya dan ketidakmampuan ekonomi untuk membelinya. Meskipun banyak dikonsumsi, seluruh responden menyatakan tidak berkeinginan mengganti nasi dengan mi instan karena nasi dianggap lebih sehat, mengenyangkan, dan murah.

Responden mengakui bahwa informasi tentang makanan olahan pabrik diperoleh dari iklan-iklan televisi. Walaupun demikian, jenis makanan yang dikonsumsi responden relatif sama, yaitu yang dijual di warung sekitar. Untuk makanan ringan, yang banyak dikonsumsi adalah jenis biskuit, keripik, dan wafer. Es krim yang dikonsumsi oleh responden dibeli dari penjual es keliling atau es krim bermerek yang dijual di warung sekitar atau minimarket terdekat. Adapun makanan olahan daging yang dikonsumsi seluruh responden adalah sosis siap saji. Bumbu racikan dan tepung bumbu paling jarang dikonsumsi karena alasan selera atau kesehatan. Adapun responden yang menggunakan bumbu racikan dan tepung bumbu beralasan menyukai rasanya dan praktis, namun jarangnya penggunaan lebih dikarenakan alasan keuangan dan ragu terhadap keamanannya.

\section{Terpaan Iklan Televisi Makanan Olahan Pabrik}

Jenis tontonan responden relatif sama, dimana waktu yang digunakan untuk menonton oleh seluruh responden untuk menonton televisi adalah pukul 19.00 hingga pukul 21.00. Tayangan yang ditonton pada waktu tersebut adalah sebuah sinetron lokal baru yang tayang di salah satu stasiun TV swasta.
Jurnal Komunikasi Pembangunan Juli 2016 Vol 14, No 2

Responden yang juga menonton pada jam lainnya antara lain menonton program berita, demo memasak, atau acara anak-anak. Iklan makanan yang paling banyak diingat adalah iklan produk baru mi instan yang saat penelitian berlangsung sedang banyak ditayangkan di televisi. Iklan berikutnya yang paling banyak ditonton adalah iklan produk makanan ringan yang dibintangi oleh salah satu pemeran utama dalam sinetron yang ditonton oleh seluruh responden.

Tabel 1 Jumlah dan persentase responden berdasarkan tingkat terpaan iklan makanan olahan pabrik di TV

\begin{tabular}{|c|c|c|}
\hline $\begin{array}{c}\text { Kategori } \\
\text { terpaan iklan } \\
\text { TV }\end{array}$ & Jumlah & $\begin{array}{c}\text { Persentas } \\
\mathrm{e}\end{array}$ \\
\hline Tinggi & 46 & 44 \\
\hline Sedang & 58 & 56 \\
\hline Rendah & 0 & 0 \\
\hline Total & 104 & 100 \\
\hline
\end{tabular}

Sebagaimana ditampilkan pada Tabel 1, tingkat terpaan iklan TV makanan olahan pabrik pada sebagian besar responden $(56 \%)$ adalah sedang, sedangkan $44 \%$ responden lainnya berada pada kategori tinggi. Tingkat terpaan iklan televisi (TV) responden dilihat dari frekuensi dan atensi responden menonton iklan TV makanan olahan pabrik. Frekuensi mencakup seberapa sering responden melihat iklan TV makanan olahan pabrik. Atensi dilihat dari perilaku responden saat menonton iklan, banyaknya iklan yang diingat, dan banyaknya unsur-unsur dalam iklan yang dapat diceritakan kembali oleh responden. Nilai tertinggi dan terendah dari total skor frekuensi dan 
ISSN 1693-3699

atensi menjadi dasar pengelompokkan tingkat terpaan menjadi tinggi, sedang, dan rendah.

Mayoritas responden $(70 \%)$ menonton iklan makanan dalam taraf sering atau setiap hari. Hanya sebagian kecil responden yang menonton iklan makanan dengan frekuensi jarang (13\%) dan sangat jarang (2\%), sedangkan $15 \%$ lainnya menonton iklan dalam taraf sangat sering. Dalam hal perilaku memperhatikan selama menonton, $40 \%$ responden menyatakan biasa memperhatikan iklan dari awal hingga akhir. Hal ini dilakukan responden karena tidak ingin ketinggalan program TV yang sedang ditontonnya.

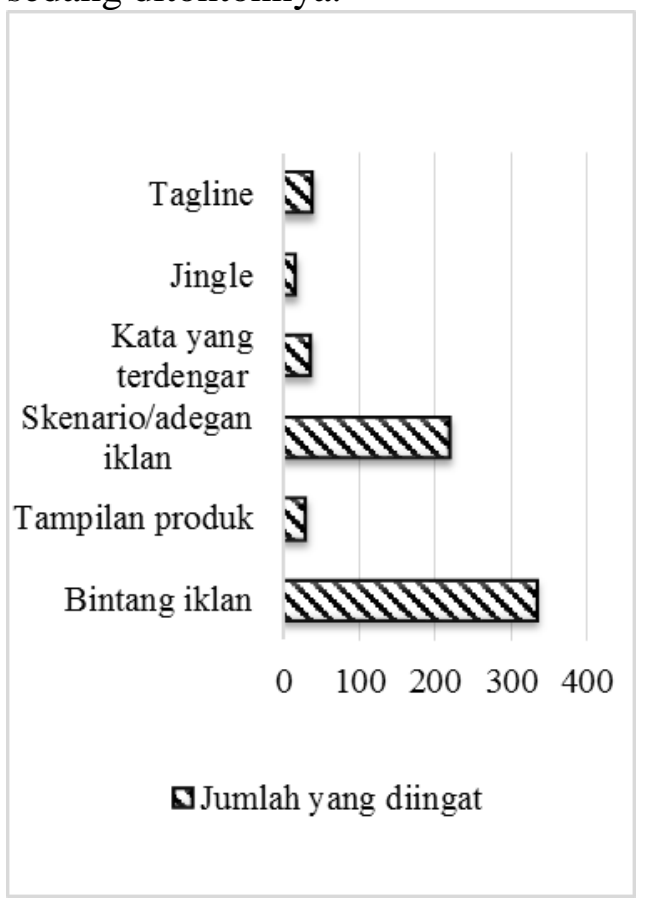

$$
\begin{array}{llr}
\text { Gambar } 6 & \text { Ingatan responden } \\
& \text { terhadap unsur-unsur } \\
& \text { daya tarik iklan }
\end{array}
$$

Sebanyak $48 \%$ responden menyatakan biasa menonton iklan makanan di TV sambil mengerjakan kegiatan lain seperti menyuapi anak dan menyeterika. Responden lainnya (12\%) biasa menonton iklan bagian
Jurnal Komunikasi Pembangunan Juli 2016 Vol 14, No 2

awalnya saja, karena saat iklan muncul di layar TV responden seringkali mengganti saluran TV ke program lainnya, kecuali jika tidak ada program lain yang menarik.

Saat menceritakan kembali iklan yang diingat, unsur daya tarik iklan makanan olahan pabrik yang paling banyak mampu diingat responden adalah selebritas yang membintangi iklan dan skenario atau adegan dalam iklan, sebagaimana terlihat pada Gambar 6. Tingkat atensi responden terhadap iklan dilihat dari skor perilaku saat menonton, ingatan terhadap iklan, dan ingatan terhadap unsur-unsur daya tarik dalam iklan. Sebagian besar responden (66\%) menonton iklan dengan atensi sedang, 24\% dengan atensi tinggi, dan selebihnya dengan atensi rendah.

\section{Sikap terhadap Makanan Olahan Pabrik}

Sikap responden terhadap makanan olahan pabrik dilihat dari reaksi evaluatif terhadap aspek-aspek dari makanan olahan pabrik yang merupakan komponen afektif, kognitif, dan konatif dari sikap.

Tabel 2 Jumlah dan persentase responden berdasarkan sikap terhadap makanan olahan pabrik

\begin{tabular}{lrc}
\hline $\begin{array}{l}\text { Tingkat } \\
\text { kognitif }\end{array}$ & Jumlah & Persentase \\
\hline Positif & 28 & 27 \\
Netral & 76 & 73 \\
Negatif & 0 & 0 \\
\hline \multicolumn{1}{c}{ Total } & 104 & 100 \\
\hline
\end{tabular}

Aspek yang dimaksud adalah yang dianggap menjadi bahan pertimbangan ibu rumah tangga dalam memilih makanan olahan untuk konsumsi keluarga. 
ISSN 1693-3699

Tabel 2 memperlihatkan bahwa sebagian besar responden (73\%) memiliki sikap yang netral, sementara 27 persen lainnya positif terhadap makanan olahan pabrik. Sikap yang netral menunjukkan sikap yang tidak memiliki keberpihakan, yaitu tidak mendukung dan juga tidak menentang makanan olahan pabrik. Sikap yang positif menunjukkan pandangan atau keyakinan, perasaan, dan niat bertindak responden yang positif terhadap makanan olahan pabrik.

Tabel 3 Jumlah dan persentase responden berdasarkan komponen kognitif sikap terhadap makanan olahan pabrik

\begin{tabular}{lcc}
\hline $\begin{array}{l}\text { Tingkat } \\
\text { kognitif }\end{array}$ & Jumlah & Persentase \\
\hline Tinggi & 73 & 70 \\
Sedang & 31 & 30 \\
Rendah & 0 & 0 \\
\hline \multicolumn{1}{c}{ Total } & 104 & 100 \\
\hline
\end{tabular}

Sebagaimana ditunjukkan pada Tabel 3, sebagian besar responden memiliki tingkat pengetahuan yang tinggi tentang makanan olahan pabrik. Tidak satupun responden yang tingkat pengetahuannya rendah. Sebagian beras responden memiliki pandangan dan keyakinan bahwa makanan olahan pabrik pada umumnya memiliki nilai gizi yang rendah $(63 \%)$, mengandung banyak zat pengawet $(62 \%)$, dan berdampak menurunkan kesehatan tubuh bila dikonsumsi secara terus menerus (71\%). Pengetahuan dan keyakinan tersebut berlawanan dengan informasi yang diberikan produsen melalui iklan TV. Makanan olahan pabrik yang diyakini aman untuk dikonsumsi oleh sebagian besar
Jurnal Komunikasi Pembangunan Juli 2016 Vol 14, No 2

responden $(64 \%)$ adalah yang telah memiliki izin dari badan POM, berlabel halal, dan belum melewati batas tanggal kadaluarsa.

Komponen afektif sikap menyangkut masalah emosional subyektif responden terhadap makanan olahan pabrik (Jain 2014). Perasaan responden terhadap makanan olahan pabrik cenderung netral (Tabel 4). Bagi seluruh responden, makanan olahan pabrik dirasa praktis. Mayoritas responden (90\%) merasa bahwa makanan olahan pabrik tidak membuat ketagihan. Dalam aspek harga, sebagian besar responden (52\%) menganggap harga makanan olahan pabrik terjangkau. Dalam aspek rasa, meski seluruh responden mengakui bahwa rasa makanan olahan pabrik enak, 70\% responden menganggap bahwa rasa makanan olahan pabrik tidak alami. Perasaan responden terhadap aspek keamanan makanan olahan pabrik beragam, dimana sebagian besar (65\%) mengkhawatirkan keamanannya. Hal ini menunjukkan bahwa perasaan responden tersebut tidak hanya bersumber dari apa yang dilihatnya dalam iklan TV.

Tabel 4 Jumlah dan persentase responden berdasarkan komponen afektif sikap terhadap makanan olahan pabrik

\begin{tabular}{lrc}
\hline Arah afektif & Jumlah & $\begin{array}{c}\text { Persentas } \\
\text { e }\end{array}$ \\
\hline Positif & 9 & 9 \\
Netral & 95 & 91 \\
Negatif & 0 & 0 \\
\hline
\end{tabular}


ISSN 1693-3699

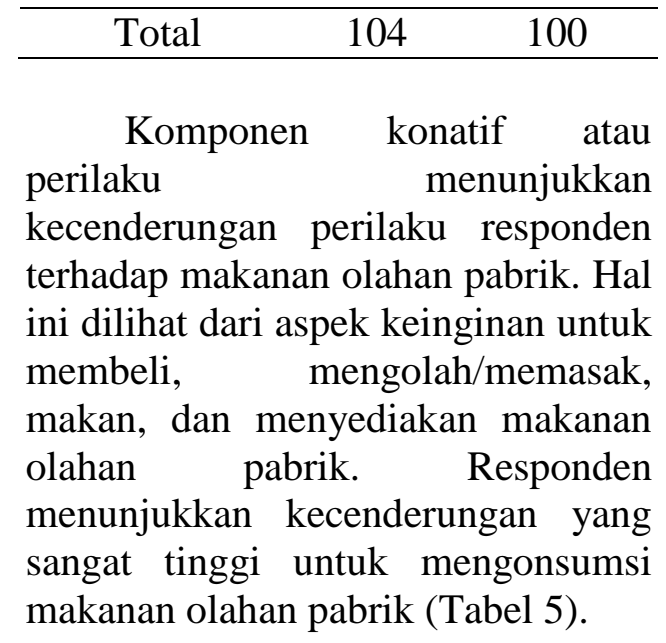

Tabel 5 Jumlah dan persentase responden berdasarkan komponen perilaku/konatif sikap terhadap makanan olahan pabrik

\begin{tabular}{lrr}
\hline $\begin{array}{c}\text { Tingkat } \\
\text { kecenderungan } \\
\text { konsumsi }\end{array}$ & Jumlah & $\begin{array}{c}\text { Persentas } \\
\mathrm{e}\end{array}$ \\
\hline Tinggi & 83 & 80 \\
Sedang & 15 & 14 \\
Rendah & 6 & 6 \\
\hline \multicolumn{1}{c}{ Total } & 104 & 100 \\
\hline
\end{tabular}

Dilihat dari setiap aspeknya, mayoritas responden memiliki keinginan untuk menggunakan makanan olahan pabrik dalam masakannya (78\%), membelinya untuk anak-anak $(77 \%)$ dan cemilan keluarga $(61 \%)$, dan menyajikan kepada tamu yang berkunjung ke rumah $(73 \%)$. Sebagian besar responden $(62 \%)$ juga menyatakan akan memilih makanan olahan pabrik yang mereknya diiklankan di TV karena dianggap lebih terpercaya dan berkualitas. Namun, makanan olahan yang dipilih oleh responden adalah yang mampu dibelinya. Keraguan sebagian kecil responden untuk mengonsumsi makanan olahan pabrik didasarkan pertimbangan keuangan dan kesehatan.
Jurnal Komunikasi Pembangunan Juli 2016 Vol 14, No 2

\section{Hubungan Terpaan Iklan TV dengan Sikap terhadap Makanan Olahan Pabrik}

Hubungan terpaan iklan TV dengan sikap responden terhadap makanan olahan pabrik dianalisis dengan uji korelasi Spearman's Rank. Sebagaimana terlihat pada Tabel 6, terpaan iklan TV makanan olahan pabrik memiliki hubungan yang cukup kuat $(r=0,254)$, sangat signifikan $(\mathrm{p}<0,01)$, dan searah.

Tabel 6 Hubungan terpaan iklan TV dengan sikap terhadap makanan olahan pabrik berdasarkan uji korelasi Spearman's Rank

\begin{tabular}{l}
\hline \\
Terpaan Koefisien korelasi $0,254^{* *}$ \\
Iklan Signifikansi (2- 0,009 \\
tailed) \\
\hline **Korelasi signifikan pada level 0,01 \\
(2-tailed) \\
Hasil ini bermakna bahwa \\
semakin tinggi terpaan iklan \\
makanan olahan pabrik pada \\
responden, semakin positif sikap \\
responden terhadap makanan olahan \\
pabrik. Hal ini berarti, semakin \\
tinggi tingkat terpaan iklan TV \\
makanan olahan pabrik pada \\
responden, semakin benar \\
pengetahuan dan keyakinannya, \\
semakin positif perasaannya, dan \\
semakin tinggi keinginan \\
konsumsinya terhadap makanan \\
olahan pabrik. Meskipun demikian, \\
iklan TV belum dapat dinyatakan \\
sebagai satu-satunya faktor yang \\
mempengaruhi sikap responden.
\end{tabular}

\section{SIMPULAN DAN SARAN}

\section{Simpulan}


ISSN 1693-3699

1. Ibu rumah tangga di wilayah pedesaan Curugbitung, Kecamatan Nanggung, Kabupaten Bogor adalah konsumen makanan olahan pabrik. Makanan olahan pabrik yang paling banyak dikonsumsi dalam taraf sering oleh responden adalah bumbu penyedap dan mi instan. Hal yang menjadi pertimbangan responden dalam mengonsumsi makanan olahan pabrik adalah ketersediaan di tempat perbelanjaan terdekat, harga, rasa, dan manfaat yang dirasa.

2. TV merupakan satu-satunya media massa yang diakses oleh hampir seluruh ibu rumah tangga di wilayah pedesaan Curugbitung, Kecamatan Nanggung, Kabupaten Bogor. Terpaan iklan TV makanan olahan pabrik pada ibu rumah tangga tersebut tergolong sedang dan tinggi, namun iklan TV bukan satu-satunya sumber informasi responden tentang makanan olahan pabrik. Responden teridentifikasi memperoleh informasi tentang makanan olahan pabrik dari program TV lain dan beberapa saluran informasi interpersonal.

3. Terjadi inkonsistensi internal antar komponen pembentuk sikap, dimana ibu rumah tangga di pedesaan memiliki pengetahuan baik tentang makanan olahan pabrik, khususnya terkait dampak negatif dari sering mengonsumsi makanan olahan pabrik, perasaan yang cenderung positif namun tidak dengan intensitas ekstrim, dan keinginan yang cenderung tinggi untuk mengonsumsi makanan olahan pabrik. Oleh karena itu, sikap responden mempunyai peluang untuk berubah ke arah positif ataupun
Jurnal Komunikasi Pembangunan Juli 2016 Vol 14, No 2

negatif, tergantung stimuli yang diterimanya. Afek atau perasaan responden tampak lebih mendominasi sikap responden dibandingkan kognisinya.

4. Tingkat terpaan iklan TV makanan olahan pabrik memiliki hubungan cukup kuat yang sangat signifikan dan searah dengan sikap ibu rumah tangga di pedesaan terhadap makanan olahan pabrik. Unsur iklan yang paling menjadi perhatian responden adalah bintang iklan dan skenario/adegan dalam iklan.

\section{Saran}

1. Pemerintah perlu melakukan upaya untuk mencegah peralihan konsumsi masyarakat desa yang berpotensi mengakibatkan pengeluaran masyarakat yang tidak efektif dan efisien serta menghambat program pembangunan ketahanan pangan di desa.

2. Pemilik media televisi diharapkan dapat memperhatikan kepentingan pemirsanya untuk memperoleh informasi yang imbang, tepat, akurat, dan benar tentang makanan olahan pabrik. Pengukuran terpaan seluruh konten TV yang terkait makanan olahan pabrik akan memperdalam kajian tentang efek kultivasi TV pada sikap terhadap makanan olahan pabrik direkomendasikan untuk penelitian selanjutnya.

3. Program-program TV atau iklan TV layanan masyarakat yang bertujuan mempengaruhi afeksi khalayak, selain memberikan informasi yang imbang, tepat, akurat, dan benar tentang makanan olahan pabrik perlu dirancang untuk menarik atensi 
ISSN 1693-3699

khalayak, khususnya ibu rumah tangga di pedesaan. Karakter bintang iklan dan jenis daya tarik emosional yang tepat untuk mempengaruhi afeksi ibu rumah tangga di pedesaan terkait keputusan pilihan konsumsi keluarga dapat menjadi topik penelitian berikutnya.

\section{DAFTAR PUSTAKA}

Ahmadi AY, Syahlani SP, Haryadi FT. 2010. Pengaruh persepsi konsumen terhadap atribut produk pada sikap terhadap produk dan niat pembelian ulang: studi empirik pengambilan keputusan pada kategori produk daging olahan beku. Buletin Peternakan.34(2): 131-137.

Arsil, Li, Bruwer. 2014. Perspectives on consumer perceptions local foods: A view from Indonesia. Journal of International Food \& Agribusiness Marketing [internet]. London (UK): Routledge. Diunduh dari http://www.tandfonline.com/loi/w ifa20. pada April 28, 2015.

Baron RA, Byrne D. 2004. Psikologi Sosial. Jilid 1. Ed ke-10. Alih

Bahasa: Ratna Djuwita dkk. Editor Wisnu C, Kristiaji, dan Ratri Medya. Jakarta (ID): Erlangga.

Bodenlos JS, Wormuth BM. 2013. Watching a food-related television show and caloric intake: A laboratory study. Appetite. 61(2013): 8-12.

Bryant J, Zillmann D. 2002. Media Effects: Advances in Theory and Research. Ed ke-2. London (UK): LEA.

Darojah U. 2012. Perubahan struktur sosial ekonomi dari ekonomi pertanian ke ekonomi industri
Jurnal Komunikasi Pembangunan Juli 2016 Vol 14, No 2

pada masyarakat Desa Kubangwungu Kecamatan Ketanggungan Kabupaten Brebes Tahun 1969-2010. Journal of Educational Social Studies. 1(2): 78-83.

Harris JL, Bargh JA, \& Brownell KD. 2009. Priming effects of television food advertising on eating behavior. Health psychology. 28(4): 404-413.

Kean LG, Prividera LC. 2007. Communicating about race and health: a content analysis of print advertisements in African American and general readership magazines. Health Communication. 21(3): 289-297.

Kean LG, Prividera LC, Boye A, Curry T. 2012. Media use, media literacy, and Afrian American female's food consumption patterns. The Howard Journal of Communications. 23: 197-214.

Kwan CW. 2012. The relationship between advertising and the level of materialism among adolescents in Hong Kong. Discovery - SS Student E-Journal. 2(201): 68-89.

Mustamar S, Sariono A, Fadah I. 2015. $\mathrm{I}_{\mathrm{b}} \mathrm{M}$ kelompok PKK petani tebu Kecamatan Jatiroto Kabupaten Lumajang [laporan pengabdian masyarakat]. Universitas Jember Digital Repository [internet]. Diunduh dari http://repository.unej.ac.id/ 123456789/65021, pada Feb 2, 2016.

Russell CA, Buhrau D. 2015. The Role of television viewing and direct experience in predicting adolescents' beliefs about the health risks of fast-food consumption. Appetite. 92(2015): 200-206.

San Joaquin AMM. 2005. Heavy, moderate, and light: Food, 
ISSN 1693-3699

nutrition, and TV viewing among children. Plaridel. 2(1): 23-44.

Setyawati T. 2013. Pergeseran pola konsumsi bahan makanan penduduk Indonesia Tahun 20022011. Dipresentasikan dalam Seminar Nasional: Menggagas Kebangkitan Komoditas Unggulan Lokal Pertanian dan Kelautan, Fakultas Pertanian Universitas Trunojoyo Madura, Juni 2013.

Sumarwan U, Simanjutak M, Yurita. 2012. Persepsi dan preferensi iklan mempengaruhi niat beli anak pada produk makanan ringan. Jur. Ilm. Kel. \& Kons. 5 (2): 185-192.

Tuu HH, Olsen SO, Thao DT, Anh NTK. 2008. The role of norms in explaining attitudes, intention, and consumption of a common food (fish) in Vietnam. Appetite. 51(2008): 546-551.

Valkenburg PM. 2004. Children's Responses to The Screen. New Jersey (US): LEA.

Warren R, Wicks R, LeBlanc Wiks J, Fosu I, Chung D. 2008. Food and beverage on US television: A comparison of child-targeted versus general audience commercials. Journal of Broadcasting and Electronic Media. 52(2):231-24. 
Jurnal Komunikasi Pembangunan

ISSN 1693-3699

Juli 2016 Vol..., No.... 